\title{
PERAN PENDIDIKAN DALAM MENYIAPKAN BISNIS TRADISIONAL MEMASUKI ERA DIGITAL
}

\author{
Budi Ilham Maliki ${ }^{1}$, Malik Fatoni ${ }^{2}$, Jaka Wijaya Kusuma ${ }^{3}$ \\ ${ }^{1,3}$ Fakultas Keguruan dan Ilmu Pendidikan \\ ${ }^{2}$ Fakultas Ekonomi dan Bisnis \\ Universitas Bina Bangsa \\ e-mail : jakawijayak@gmail.com
}

\begin{abstract}
The inability of business people to take advantage of opportunities and unpreparedness to face challenges in the digital age turned out to create problems. This is especially true among business people who are still traditional or conventional.By using this research method the writer can easily solve the problem that wants to be investigated.The results of the study of literature study conclude that traditional business is a business that is managed using a traditional economic system that aims to meet the needs of life by doing habits or hereditary traditions. Traditional business is conducted with minimal management and family-based. Whereas modern business (including online business) is a business that uses a capital economic system, which has the characteristics of specialization, interdependence, and mass production. Business opportunities and challenges in the digital age include rapid technological developments, rapid flow of information, more and more competitors, fast-paced demands, changing societies, demands for continuous learning, innovation in creating products, thinking out of the box, being able to compete in a healthy manner, digital transformation, speed, adaptive human resources, higher competition, and a lack of support from leaders. The role of education in the digital era includes (1) strengthening science and developing creativity, (2) developing digital education, participatory relationships, and values education, (3) reorienting learning, (4) changing the role of consumers as well as becoming producers, (5) produce graduates who are ready to work, adaptive, and competitive, (6) empowers students in the application of science and technology, (7) optimizes non-formal education services for community empowerment, especially traditional business people in the digital age.
\end{abstract}

\section{Keywords: Role of Education, Traditional Business, Digital Era}

\begin{abstract}
Abstrak: Ketidakmampuan para pelaku bisnis memanfaatkan peluang dan ketidaksiapan mengahadapi tantangan di era digital ternyata memunculkan permasalahan. Hal ini terutama terjadi di kalangan para pelaku bisnis yang masih tradisional atau konvensional. Dengan menggunaan metode kajian secara mendalam terhadap konsep dan teori yang digunakan berdasarkan literatur yang tersedia. Penelitian studi pustaka menyimpulkan bahwa bisnis tradisional adalah bisnis yang dikelola menggunakan sistem ekonomi tradisional yang bertujuan memenuhi kebutuhan hidup dengan melakukan kebiasaan atau tradisi turun-temurun. Peluang dan tantangan bisnis di era modern ini antara lain meliputi perkembangan teknologi yang kian pesat, derasnya arus informasi, kompetitor semakin banyak, tuntutan serba cepat, masyarakat yang berubah, tuntutan terus menerus belajar, inovatif dalam menciptakan produk, berpikir out of the box, mampu bersaing secara sehat, transformasi digital, kecepatan, sumber daya manusia yang adaptif, persaingan semakin tinggi, dan kurangnya dukungan pemimpin. Peran pendidikan di era digital antara lain meliputi (1) memperkuat sains dan mengembangkan kreativitas, (2) mengembangkan pendidikan digital, hubungan partisipatif, dan pendidikan nilai, (3) mereorientasi pembelajaran, (4) mengubah peran kosumen sekaligus menjadi produsen, (5) menghasilkan lulusan siap kerja, adaptif, dan kompetitif, (6) memberdayakan peserta
\end{abstract}


didik dalam aplikasi sains dan teknologi, (7) mengoptimalkan pelayanan pendidikan non formal bagi pemberdayaan masyarakat, khsusnya pelaku bisnis tradisional di era digital.

\section{Kata kunci: Peran Pendidikan, Bisnis Tradisional, Era Digital}

\section{PENDAHULUAN}

Era sekarang ini perkembangan teknologi yang serba digital semakin cepat sehingga zaman sekarang ini disebut sebagai era digital. Pada era digital saat sekarang ini manusia secara umum dapat menampilkan pola gaya hidup baru yang serba elektronis. Hampir sebagian besar kebutuhan manusia tidak terlepas dari peran perangkat teknologis. Teknologi telah nyata berperan mempermudah manusia melakukan tugas dan pekerjaan apapun, sehingga membawa peradaban kehidupan manusia memasuki era digital. Salah satu bentuk penerapan teknologi dalam pendidikan adalah berkembangnya konsep e-Learning. Konsep pembelajaran e-Learning adalah sebuah istilah dikenal di luar maupun dalam negeri. eLearning adalah sebuah konsep pembelajaran yang menggunakan teknologi computer yang daapt disebarkan dan diakses melaui perangkat komputer (Herlandy \& Novalia, 2019). Era digital kehidupan manusia telah membawa banyak dampak positif berupa berbagai perubahan yang baik, namun sekaligus juga membawa banyak dampak negatif yang menjadi tantangan baru bagi manusia dalam kehidupan era digital ini. Tantangan itu bahkan telah memasuki berbagai bidang seperti politik, ekonomi/bisnis, sosial budaya, pertahanan, keamanan, dan teknologi informasi itu sendiri. Berdasarkan hasil survei dari Asosiasi Penyelenggara Jaringan Internet Indonesia (APJII) pada tahun 2017 dapat diketahui bahwa jumlah pengguna internet di Indonesia jumlahnya sebanyak 143,26 juta orang dengan jumlah penduduk Indonesia 262 juta orang. Data ini menunjukkan bahwa lebih dari separuh pengguna internet jika dibandingkan jumlah penduduk Indonesia dengan persentase sebesar $54,68 \%$ dan pemanfaatan jaringan internet juga disertai dengan berkembangnya penggunaan telepon genggam dan komputer/laptop, dengan usia pengguna bervariasi, sesuai dengan kebutuhan masing-masing seperti media sosial, permainan, menjelajah (browsing), transaksi jual beli, dan sebagainya (Defrizal et al., 2019).

Tantangan sekaligus peluang di era digital khususnya dalam bidang bisnis antara lain seperti adanya perkembangan teknologi yang kian pesat, derasnya arus informasi, kompetitor semakin banyak, tuntutan serba cepat, masyarakat yang berubah, tuntutan terusmenerus belajar, inovatif dalam menciptakan produk, berpikir out of the box, mampu bersaing secara sehat, transformasi digital, kecepatan, sumber daya manusia yang adaptif, persaingan semakin tinggi dan Ketersediaan internet sebagai kebutuhan utama dalam pemasaran. Penggunaan internet sebagai media pendidikan dapat dianggap sebagai suatu hal yang sudah jamak digunakan(Putra, 2019). Semua hal tersebut tentu menuntut kemampuan dan kesiapan yang memadai dari para pelaku bisnis untuk menghadapi semua itu secara baik.

Kemampuan dan kesiapan pelaku bisnis yang kondusif dalam memanfaatkan peluang dan menghadapi tantangan bisnis di era digital tentu akan memberikan banyak keuntungan. Sebaliknya, apabila pelaku bisnis tidak memiliki kemampuan dan kesiapan yang memadai dalam menghadapi peluang dan tantangan era digital tersebut maka kerugian yang akan didapatkan, bahkan akan menimbulkan konflik sosial dengan pihak pelaku bisnis yang telah memiliki kemampuan dan kesiapan. Berbagai literatur telah memberikan bukti empiris bahwa keselarasan strategi bisnis dan digital sangat mempengaruhi kualitas tata kelola di dalam sebuah organisasi. Keselarasan antara strategi bisnis dan pemanfaatan teknologi menyebabkan kualitas implementasi menjadi lebih efektif serta mendukung kinerja yang lebih tinggi pada perusahaan-perusahaan berskala kecil dan menengah (Alami, 2019) 
Fenomena ketidakmampuan dan ketidaksiapan pelaku bisnis dalam memasuki era digital ini dapat dilihat pada kalangan pebisnis yang masih bertahan dengan pola tradisional atau konvensional. Hal ini pada realitasnya telah menimbulkan masalah, bukan saja masalah yang terkait dengan ekonomi, melainkan juga masalah kehidupan sosial, bahkan masalah lainnya sebagai dampak negatif pengiring. Kasus penolakan keras kalangan pelaku bisnis bidang jasa transportasi ojek pangkalan terhadap ojek online (go-jek) yang terjadi di berbagai daerah merupakan salah satu fenomena yang menunjukkan ketidakmampuan dan ketidaksiapan mereka dalam menyikapi tuntutan bisnis jasa trasportasi di era digital yang harus cepat, praktis, hemat, dan teknologis. Fenomena tersebut bukan saja menjadi persoalan bisnis semata, tetapi juga sudah masuk pada persoalan dan masalah konflik sosial, pelanggaran hukum, bahkan politis. Sementara itu, pemerintah pun tidak mampu mengantisipasi dan mengelola persoalan tersebut secara efektif sehingga diperlukan solusi yang bijak, baik secara ekonomis (tidak merugikan salah satu pihak), sosial (tidak menimbulkan konflik), edukatif (perlu edukasi), dan politis (adanya kemauan politik pemerintah untuk mengatasi masalah).

Sehubungan dengan latar belakang tersebut timbul beberapa pertanyaan: Apakah bisnis tradisional itu dan perbedaannya dengan bisnis modern? Apa saja peluang dan tantangan bisnis di era digital? Bagaimana peranan pendidikan dalam mempersiapkan sumber daya manusia, khusuynya pelaku bisnis tradisional memasuki era digital? Sejalan dengan rumusan masalah tersebut penelitian ini bertujuan mendeskripiskan (1) perbedaan bisnis tradisional dengan bisnis modern (era-digital), (2) peluang dan tantangan bisnis di eradigital, dan (3) peranan pendidikan dalam mempersiapkan sumber daya manusia, khususnya pelaku bisnis tradsional memasuki era digital.

\section{METODE PENELITIAN}

Metode yang digunakan untuk menjawab pertanyaan penelitian diatas adalah menggunakan metode penelitian Kualitatif dengan pendekatan studi studi kepustakaan atau kajian pustaka, yakni sebuah upaya pengkajian secara mendalam dan anlitis yang berisi teori teori yang relevan dengan masalah - masalah penelitian. Penggunaan metode ini diharapkan dapat menemukan makna terdalam dari fenomena yang ada sehingga mendapatkan dan menemukan serta lahirnya sebuah konsep teori baru. Hal ini dilakukan karena pengkajian dalam aspek masalah ini dihubungkan atas konsep dan teori yang digunakan berdasarkan literatur yang tersedia. Kajian kepustakaan ini berfungsi untuk membangun kerangka konsep atau teori yang analitis dan konstrukif yang menjadi dasar studi dalam penelitian. Dengan menggunakan metode penelitian ini penulis dapat dengan mudah menyelesaikan masalah yang hendak diteliti tersebut (Wiratna Sujarweni \& Laut Mertha Jaya, 2019).

\section{HASIL DAN PEMBAHASAN}

a. Bisnis Tradisonal dan Perbedaanya dengan Bisnis Modern

Bisnis sudah ada sejak manusia diciptakan. Sistem bisnis terus menerus mengalami perkembangan seiring dengan majunya zaman. Saat ini bisnis yang sangat digandrungi adalah bisnis online yang memanfaatkan jaringan internet dan penggunaan smartphone. Apa yang dimaksud dengan bisnis tradisional? Bisnis tradisional adalah bisnis yang dikelola menggunakan sistem ekonomi tradisional di mana setiap aktivitas perekonomian dilakukan bertujuan untuk memenuhi kebutuhan hidup dengan melakukan kebiasaan atau tradisi turun temurun. Bisnis tradsional dilakukan untuk memenuhi kebutuhan hidup, minim manajemen, dan berdasarkan kekeluargaaan. Sedangkan yang dimaksud dengan bisnis modern? Bisnis modern (mencakup bisnis online) adalah bisnis yang menggunakan sistem ekonomi kapital, yang memiliki ciri-ciri spesialisasi, saling ketergantungan, dan berproduksi secara massal. 
Bisnis ini tujuan utamanya adalah profit atau keuntungan. Bisnis modren cenderung memiliki kapasitas dan skala usaha yang lebih luas, dengan jangkauan setiap kota atau bahkan setiap negara.

Bisnis tradisional yang berpola kekeluargaan sangat sulit dan tidak mudah untuk mengalami konflik internal dalam suatu bisnis. Sementara bisnis modern yang cenderung bertujuan untuk mencari profit, lebih rentan untuk mengalami konflik internal dan dampak negatif yang ditimbulkan dari limbah atau sisa dari produksi karena sudah melakukan kegiatan bisnis dalam skala besar. Namun kelebihan bisnis modern tentunya memiliki efektivitas dan efisiensi yang tinggi, karena menggunakan manajemen dan teknologi terbaru untuk produksi barang atau jasa. Selain itu bisnis modern juga dapat menjadi solusi bagi tingginya pengangguran karena dapat menyerap tenaga kerja yang jauh lebih besar.

Secara umum yang membedakan antara bisnis tradisional dan bisnis modern adalah skala usaha dan pola manajemennya. Lebih jelasnya perbedaan di antara kedua bisnis tersebut dapat diuraikan dari aspek-aspek antara lain sebagai berikut:

1) Aspek Pola Merintis dan Mengembangkan Bisnis

Dari segi pembangunan bisnis, pelaku bisnis tradisional cenderung merintis bisnisnya dengan kemampuan apa adanya sesuai dengan modal yang dia miliki. Sedangkan bisnis modern akan mencari sumber investor yang bisa membantunya merintis usaha, yang kemudian memulai bisnis berdasarkan masalah yang dialami, apa yang ditemukan, serta memberikan solusi kepada lingkungan.

2) Aspek Pelayanan terhadap Konsumen

Ketika berbicara mengenai konsumen atau pelanggan pebisnis tradisional lebih sering memenuhi berbagai permintaan konsumen yang dirasa cukup penting sehingga produk yang dihasilkan lebih bervariasi berdasarkan permintaan dari konsumen. Sedangkan pebisnis modern melayani konsumen dengan cara pemberian solusi yang terbaik, bukan dengan memberikan apa yang konsumen mau secara teknis.

3) Aspek Mitra Bisnis

Dalam bisnis tradisional lebih sering mengandalkan keluarga atau orang yang dikenal untuk saling bermitra, sehingga kegiatan bisnis dinilai tidak efektif dan efisien serta profesional. Sedangkan untuk bisnis modern lebih suka untuk mempekerjakan orang-orang yang profesional begitu juga dengan mencari klien atau Mitra bisnis.

4) Aspek Harga

Dari aspek harga, bisnis tradisional memiliki kelebihan karena memang menggunakan modal dan sumber daya yang relatif lebih sedikit dibanding dengan bisnis modern. Harga yang ditawarkan bisa sangat bervariasi namun secara keseluruhan bisnis tradisional lebih menawarkan harga yang lebih terjangkau.

5) Jenis Barang atau Jasa

Dari segi aspek barang atau jasa yang ditawarkan, bisnis tradisional banyak yang menawarkan dan memberikan pilihan apa yang dibutuhkan oleh masyarakat secara luas, sementara bisnis modern memberikan apa yang dibutuhkan oleh pangsa pasar yang lebih luas. Sementara produk yang ditawarkan oleh bisnis modern lebih bervariasi, dan terdapat juga barang yang berasal dari luar negeri atau barang impor.

6) Aspek Pemasaran

Salah satu aspek yang paling menonjol yang membedakan antara bisnis modern dengan bisnis tradisional adalah dari segi marketing. Pada dasarnya marketing tradisional adalah marketing yang dilakukan sebelum adanya jaringan internet, dan minim manajemen. Sementara pemasaran modern lebih mengandalkan jaringan internet yang biasa disebut sebagai pemasaran online. Marketing yang menggunakan strategi seperti pembuatan website, pengoptimalan SEO pembuatan iklan banner dan optimasi media sosial. 


\section{7) Aspek Skala Usaha}

Umumnya, bisnis dengan orientasi tradisional memiliki skala dan omset usaha yang relatif lebih kecil dibanding dengan bisnis yang modern. Hal ini karena perbedaan pola pikir pemiliknya serta adanya penunjang modal dan manajemen bisnis yang lebih matang pada bisnis modern. Namun tidak menutup kemungkinan bisnis tradisional bisa berubah menjadi modern apabila dilakukan restrukturisasi, sehingga merubah orientasi bisnisnya menjadi lebih baik lagi.

8) Aspek Manajemen Bisnis

Manajemen bisnis adalah salah satu modal yang paling penting untuk memulai bisnis. Dan ini yang membedakan antara bisnis tradisional dengan bisnis modern. Bisnis tradisional, tidak memiliki manajemen yang matang, cenderung memiliki rencana bisnis jangka pendek, tidak ada evaluasi setelah sekian lama bisnis berjalan, dan sebagainya. Berbeda dengan bisnis modern yang memang sudah matang dalam hal manajemen internalnya.

Selanjutnya dibedakan juga antara wirausahawan tradisional dan wirausahawan modern, antara lain, sebagai berikut.

1) Peluang vs Problem

Kegiatan wirausahawan yang dilakukan secara tradisional biasanya memulai bisnis karena melihat peluang. Peluang datang misalnya berasal dari tawaran rekan atau koneksi, melihat dari keberhasilan bisnis orang lain yang berhasil, trend konsumen, aset yang dimiliki, atau juga dari kemampuan dan skill yang dikuasai calon wirausahawan. Sedangkan wirausahawan yang bergaya modern memulai dan berangkat dari problem yang dialami, ditemukan, atau dilihat. Berangkat dari situasi tersebut seseorang dapat berhasil menemukan solusi untuk di pecahkan problem atau masalahnya itu, kemudian mengetahui bahwa problem itu benar nyata dan lahirlah solusi untuk kemudian dinilai memiliki market yang baik.

2) Kompleks vs Sederhana

Fakta di masyarakat bahwa apa yang dilakukan wirausahawan tradisional akan dihadapkan pada usaha memenuhi berbagai kebutuhan dan beragam keinginan banyak orang, juga beragam keinginan trend atau style yang memberikan masukan kepadanya. Sehingga luaran produk atau service yang diberikan kepada masyarakat akan makin kompleks dan beragam, banyak, dan beragam fiturnya. Sedangkan apa yang dialami wirausahawan modern berupaya untuk terus-menerus fokus kepada solusi dari problem utama berangkat dari ide konsumen, kemudian berusaha menyederhanakan solusinya, membuatnya makin mudah di pahami dan di mengerti konsumen. Sehingga terkadang sering terjadi wirausahawan modern malah memangkas produk, service, atau fitur demi membuat konsumen makin menikmati solusi terbaik bagi problemnya.

3) Termurah vs Terbaik

Kegiatan usaha yang dilakukan oleh wirausahawan yang tradisional biasanya cenderung untuk melakukan penghematan dalam menggaji karyawan, bahkan melakukan upaya apapun terhadap karyawan yang di dalam tim manajemen ataupun yang posisinya langsung dibawahnya untuk mengikuti intruksi dan petunjuknya. Pola pikir yang di bangun adalah bahwa lebih baik dikerjakan sendiri daripada bayar orang yang relatif lebih mahal. Sementara apa yang terjadi dilakukan oleh seorang wirausahawan modern biasanya akan berusaha melakukan upaya apapun dalam merekrut orang terbaik di bidangnya, karena dia tahu bahwa profesional terbaik akan bisa menjadi sparring partner internal baginya sekaligus katalisator pertumbuhan bagi tujuan usahanya. Selain itu, dengan memiliki orang-orang terbaik, membuat pekerjaan wirausahawan menjadi lebih ringan dan simple karena bisa mendelegasikan pekerjaan kepada karyawan dan dirinya akan lebih fokus kepada hal-hal yang lebih strategis. Sebagai bentuk penghargaan biasanya mereka akan diberikan upah atau gaji lebih besar sesuai dengan kompetensinya, bahkan lebih besar daripada gajinya sendiri. 
Kebiasaan lainnya yang dilakukan oleh wirausahawan modern adalah terbiasa merekrut partner kerja baru bagi upaya mendukung bisnisnya untuk saling melengkapi kekuatan.

4) Pengulangan vs Naik Kelas

Apa yang terjadi dengan karakter wirausahawan tradisional kecenderungannya berusaha mengulangi keberhasilan apa yang terjadi dengan bisnisnya dalam keadaan dan situasi tertentu, biasanya membuat bisnis yang sama persis atau mirip hanya berbeda produknya. Misal bila dia berhasil membuat bisnis soto beromset Rp $1 \mathrm{M}$, maka dia akan berusaha membuat bisnis pecel beromset Rp $1 \mathrm{M}$, dan seterusnya. Sementara untuk karakter wirausahawan modern sering berpikir dan bertindak akan berusaha naik kelas. Apabila berhasil membuat bisnis soto beromset $\mathrm{Rp} 1 \mathrm{M}$, maka dia berusaha membuat bisnis sotonya menjadi beromset Rp 10 M, Rp 100 M, dan seterusnya. Karakter ini sanagat melekat pada wirausahawan modern karena dia tidak segan-segan untuk terus belajar dan mengembangkan manajemennya, karena ada banyak sekali belajar dari pengalaman dan perbedaan berbisnis diluar sana untuk dapat kita pahami konsepnya agar mampu menciptakan dan mengelola bisnis yang memiliki omset 10 kali lipat lebih besar.

5) Stagnan vs Moving Target

Sifat yang ada dalam seorang wirausahawan tradisional terkadang akan cepat merasa puas dan merasa sudah sukses, kemudian cenderung berkata "selama ini juga jalan kok". Sementara wirausahawan modern akan berfikiran dan beranggapan bahwa "life is a moving target", sehingga cenderung tak pernah merasa puas dan selalu "lapar" dan terbuka peluang untuk terus berinovasi. Jadi mereka akan selalu terbuka terhadap inovasi, bahkan kadang menampilkan perubahan drastis, agar bisnisnya makin berkembang dan maju.

\section{b. Peluang dan Tantangan Bisnis di Era Digital}

1) Perkembangan Teknologi

Perkembangan teknologi yang semakin pesat, kita melihatnya seperti pisau bermata dua, di satu sisi keberadaan teknologi memudahkan segala kegiatan dan pekerjaan yang dilakukan manusia, termasuk apa yang digunakan manusia untuk memaksimalkan keuntungan bisnis. Di sisi lain mereka yang tidak paham teknologi, akan tergilas oleh zaman. Bisnis yang dapat dipadukan dengan keberadaan teknologi dapat melaju lebih pesat dan akan terus berkembang karena akan terus mengikuti perkembangan pasar yang menuntut segala sesuatunya untuk cepat berubah.

\section{2) Arus Informasi}

Selain perkembangan dan tuntutan pemanfaatan teknologi, dampak lain semakin meluasnya penggunaan internet di kalangan masyarakat adalah derasnya arus informasi. Ini merupakan sebuah keadaan realitas dan menjadi sebuah tantangan yang harus dihadapi oleh para pelaku bisnis di era digital. Semakin banyak kita memperoleh informasi yang tersedia, maka konsumen pun akan semakin pintar dalam memilih produk yang dibutuhkan. Artinya pelaku bisnis dihadapkan pada realitas persaingan bisnis yang sangat kompetitif. Jika tidak pandai memanfaatkan situasi, hal ini dapat berdampak buruk terhadap bisnis. Namun jika dapat menggunakan kesempatan ini untuk mengembangkan bisnis menjadi lebih baik dari yang lain, maka prospek bisnis dan raihan keuntungan pada bisnis akan bertambah.

3) Kompetitor Semakin Banyak

Kehadiran teknologi sangat penting, tanpanya bisnis yang kita kelola akan berkembang dengan lambat. Namun dengan dukungan teknologi, ada banyak realisasi target yang tercapai dan apa yang menjadi kebutuhan konsumen dapat dapat dipenuhi dengan maksimal. Apabila kegiatan bisnis kita tidak disertai dengan inovasi yang kreatif, ia tidak dapat bertahan lama di pasar. Untuk itu, selalu ciptakan inovasi. Ciptakan sesuatu produk apa saja yang unik yang tidak pernah ditemui sebelumnya, agar dapat menarik perhatian para konsumen. 


\section{4) Serba Cepat}

Masyarakat yang hidup di era digital menginginkan sesuatu yang serba cepat dan praktis. Caranya dengan bagaimana kita dapat memanfaatkan teknologi tersebut. Jika sebagai pelaku bisnis tidak dapat menandingi kecepatan tersebut, maka bisnis yang kita jalankan tidak dapat berhasil dengan baik, bahkan bisnis kita bisa kalah dari bisnis-bisnis lain yang mampu memanfaatkan teknologi untuk perkembangan bisnisnya.

5) Masyarakat yang Berubah

Masyarakat sekarang berbeda dengan masyarakat pada zaman dahulu. Perubahan masyarakat bergerak secara dinamis, bahkan tidak lagi bersifat evolusi namu mengarah kepada revolusi. Hal ini menjadi tantangan tersendiri bagi para pelaku bisnis yaitu upaya bagaimana kemampuan kita dalam mengemas suatu produk bisnisnya, sehingga fungsinya saat ini berubah bukan hanya memuaskan konsumen, tetapi juga sebagai fungsi tambahan yakni style. Perubahan tersebut bisa dijadikan sebagai peluang bisnis. Meskipun keinginan konsumen semakin kompleks, itu berarti pelaku bisnis memiliki kesempatan untuk terus tidak berhenti dalam berinovasi. Masyarakat modern cenderung lebih terbuka terhadap inovasi dan senang mencoba hal-hal yang baru. Bagi para pelaku bisnis yang ingin menikmati keuntungan di era digital ini, ada banyak bisnis yang bisa dijalankan sebagai peluang meraih keuntungan capital dalam dunia bisnis sekarang ini.

6) Terus Menerus Belajar

Pelaku bisnis harus pandang melihat persoalan tentang peluang dan tantangan bisnis di era digital sekarang ini. bagaimana pelaku binsis tersebut untuk terus belajar dan tiada berhenti dalam menuangkan ide kreatifitasnya dalam menjalankan bisnis, baik belajar secara mandiri maupun belajar dari orang yang ahli. Dengan banyak belajar, pelaku bisnis dapat melakuakn kreativitas dan inovasi dalam usaha meningkatkan dan mengembangkan bisnisnya.

7) Inovatif Dalam Menciptakan Produk

Peluang dan tantangan bisnis di era digital yang datang bersamaan selanjutnya adalah kemampuannya melakukan inovasi dari sebuah kegiatan usaha bisnisnya. Ini adalah tantangan yang menuntut para pelaku bisnis untuk melakukan inovasi dalam banyak hal dalam mengembangkan produk yang dimilikinya agar semakin mudah disukai oleh orang banyak dan selalu menjadi pilihan terbaik dari konsumen.

\section{8) Berpikir Out Of The Box}

Berpikir out of the box atau berbeda dari yang lain sangat diperlukan pada saat pelaku bisnis ingin membuat bisnisnya sukses dan berhasil. Banyak diantara kita yang berfikir sesuatu yang umum dilakukan, tetapi alangkah baiknya jika berpikir sesuatu yang tidak umum, yakni yang berfikir kreatif dan inovatif sehingga target sasaran keberhasilan usahanya dapat diraoh secara maksimal. Pada dasarnya bukanlah sesuatu yang mudah untuk mendapatkan semua apa yang menjadi ide bisnis dengan cara yang biasa, tetapi kita perlu melakukan sesuatu yang luar bisa atau unik dalam berinovasi terhadap bisnis kita.

9) Mampu Bersaing Secara Sehat

Persaingan bisnis saat ini berbeda dengan masa sebelumnya, saat ini nilai kompetisi dalam dunia bisnis semakin keras dan ketat, sehingga menuntut para pelaku bisnis untuk meningkatkan kemampuan kompetitifnya secara sehat dengan terus banyak belajar, berkerativitas, berinovasi, bereksperientasi, dan berkolaborasi. Dalam dunia bisnsi bersaing secara sehat berarti bersaing dengan meningkatkan kemampuan untuk menghasilkan keunggulan-keunggulan yang tidak dimiliki pebisnis yang lain dan disukai pasar.

10)Transformasi Digital

Transformasi digital yang setiap hari makin maju dan canggih memang memiliki banyak sekali manfaat untuk perkembangan dunia bisnis saat ini. Teknologi dapat menghemat waktu, tenaga, serta biaya dengan hasil yang cukup maksimal. Namun, transformasi ini bisa akan menjadi sebuah tantangan yang cukup berarti apabila bisnis yang dijalankan tidak dapat 
mengikuti perkembangan trend pasar dan kemauan konsumen. Apalagi, adanya ketakutan untuk mengubah cara-cara lama dalam berwirausaha akan dapat menimbulkan kekhawatiran ditinggalkan konsumen apabila transformasi yang dilakukan tidak sesuai dengan yang diharapkan atau justru gagal. Hal ini perlu disikapi dengan rasa optimis yang tinggi dan pantang menyerah dalam berusaha. Sebuah bisnis harus bisa menyesuaikan diri dengan teknologi yang terus berkembang. Pemilik bisnis akan dituntut untuk terus belajar dan belajar dan terus berinovasi. Memang terdengarnya akan menguras waktu dan tenaga, namun apabila berhasil nantinya akan sangat mempermudah jalannya bisnis.

11) Kecepatan

Layaknya teknologi yang menuntut pemilik bisnis untuk adaptif, kehadirannya sangat cepat menangkap perubahan sosial dalam kehidupan masyarakat saat ini, hal ini pun menuntut produk dan layanan yang serba cepat serta praktis. Dan jika pemilik bisnis tidak dapat beradaptasi dengan baik dan cepat dalam memenuhi keinginan ini, konsekuensinya bisnis akan ditinggalkan oleh konsumen secara perlahan bahkan ditinggalkan selamnya. Pemilik bisnis dapat mengatasinya semua persoalan itu dengan berkolaborasi dengan teknologi yang ada saat ini. Bisnis yang dipadukan dengan teknologi dapat melaju lebih pesat karena mengikuti perkembangan pasar.

12) Sumber Daya Manusia

Teknologi sudah diadopsi dalam berbagai kebutuhan hidup masyarakat termasuk didalamnya dalam dunia bisnis, namun masih ada beberapa pekerjaan rumah lagi yang harus diselesaikan terkait pemanfaatan teknologi dalam kehidupan, yakni membuat sumber daya manusia yang dipekerjakan juga adaptif terhadap teknologi tersebut. Jangan sampai biaya besar yang dikeluarkan untuk pembaharuan teknologi malah tidak dapat dioptimalkan dengan baik karena orang-orang yang terlibat didalamnya tidak mampu untuk menggunakannya untuk sebuah hal besar dalam hidup. Sebuah bisnis yang ingin berjalan secara profesional dan berkembang butuh untuk merekrut sumber daya manusia yang memiliki kemampuan yang baik. Selain itu, pemilik bisnis juga sebaiknya melakukan terobosan dan memberikan pelatihan tambahan serta melakukan upgrade keilmuan kompetensi kepada karyawannya secara berkala untuk menyesuaikan diri dengan perkembangan ilmu pengetahuan dan teknologi.

\section{3) Persaingan Semakin Tinggi}

Lagi-lagi berbicara tentang teknologi tidak akan pernah habisnya karena teknologi mempunyai pengaruh besar dalam kehidupan manusia. Teknologi canggih mampu mengintegrasi keseluruhan kehidupan manusia termasuk didalamnya untuk saluran bisnis sehingga dapat dilakukan tanpa batasan ruang dan waktu. Efeknya, sebuah bisnis bisa menjalin kerja sama dengan bisnis lain di belahan dunia mana saja tanpa ada penghalang apapun. Dan tentu saja, sebuah bisnis juga mendapatkan kompetitor dari berbagai bisnis lain di belahan dunia mana saja pula. Jika tidak dibarengi dengan inovasi yang harus terus menerus dilakukan, maka bisnis akan tertinggal dari kompetitor. Selain itu, tantangan lain yang kita sering temukan ketika berhubungan dengan kompetitor adalah bagaimana caranya kita berupaya untuk bersaing secara sehat. Karena pada dasarnya hal tersebut memang sangat penting untuk diterapkan. Jika kita mampu bersaing secara sehat, maka akan terbentuk iklim yang baik dalam bisnis.

\section{4) Kurangnya Dukungan Pemimpin}

Bisnis saat ini sangat praktis dalam menjalankannya dengan dukungan kemajuan teknologim kegiatan bisnis bisa dilakukan dan dikontrol dari jarak yang cukup jauh dengan menggunakan beberapa aplikasi dan saran teknologi yang berbasis digital seperti website, email, dan fitur chatting sosmed dan lain sebagainya. Namun permasalahan yang kerap terjadi ketika menggunakan metode ini yang menempatkan pola komunikasi jarak jauh dalam kegiatan bisnis adalah hilangnya sosok pemimpin. Pemilik bisnis kerap berkomunikasi dengan 
karyawannya hanya mengenai hal-hal yang berhubungan bisnis. Sehingga intensitas pertemuan langsung antara karyawan dengan pemimpin perusahaan terjadi sangat minim sekali. Padahal karyawan membutuhkan keakraban dengan pemimpinnya untuk menjalin komunikasi yang baik dan menambah semangat untuk bekerja. Oleh karena itu, pemilik bisnis sebaiknya membuat suatu kegiatan yang dapat mengakrabkan karyawan, pihak manajemen dan juga pemilik bisnis sendiri.

c. Peran Pendidikan di Era Digital

1) Kebutuhan Sumber Daya Manusia Di Era Digital (Abad 21)

Secara umum terkait dengan kebutuhan SDM sekarang ini kita dapat diidentifikasi ada tujuh keahlian yang harus dimiliki agar tetap survive di era informasi atau digital yaitu: (1) kemampuan berfikir kritis dan kemauan bekerjakeras, (2) kreativitas, (3) kalaborasi, (4) pemahaman antar budaya, (5) komunikasi, (6) mengopersikan komputer, (7) kemampuan belajar secara mandiri. Manusia modern abad 21 harus mampu berfikir kritis dan kemauan tangguh untuk kerja keras, mereka dituntut mampu mendefinisikan dan menterjemahkan beberapa permasalahan kehidupan yang sangat kompleks dan tumpang tindih, tidak jelas domainnya; menggunakan keahlian dan perangkat yang tersedia baik manusia maupun elektronik untuk analisis dan riset; mendesain jenis tindakan dan solusi; mengatur implementasi solusi tersebut; menilai hasil; kemudian secara terus-menerus meningkatkan variasi solusi ketika kondisi berubah.

Manusia pada abad modern ini harus kreatif mampu menciptakan solusi baru untuk permasalahan lama, menemukan prinsip baru dan penemuan baru untuk menjawab tantangan yang ada, menciptakan cara baru untuk mengkomunikasikan gagasan baru, menemukan cara kratif untuk mengatur proses kompleks. Dalam kehidupan ini manusia harus mampu kerjasama kelompok dalam banyak hal untuk memecahkan masalah yang rumit atau untuk menciptakan perangkat kompleks, menghasilkan jasa, dan produk-produk. Kehidupan era informasi dan digitalisasi, dimana tidak ada sekat antar negara maka diperlukan kemampuan memahami eksistensi budaya antar negara tanpa kehilangan akar budayanya sendiri (karakter kebangsaan). Sebagai suatu perluasan kerjasama kelompok, untuk itu manusia harus menjembatani adanya perbedaan etnik, sosial, organisasi masyarakat, ideology politik, dan isi kultur pengetahuan dalam rangka melakukan pekerjaan mereka. Peningkatan eksistensi kehidupan manusia yang multikultural di masyarakat terus-menerus di jaga, pertumbuhan ekonomi global, peningkatan dunia teknik, dan model organisasi "jaringan" keterampilan lintas budaya tanpa kehilangan identitas asli "budayanya" akan menjadi semakin berharga.

Untuk menjawab tantangan dan problematika itu kita memerlukan kemampuan untuk berkomunikasi efektif di dalam berbagai media dengan berbagai pendengaran. Dengan berusaha memberikan sejumlah pilihan komunikasi misalnya; laporan tercetak, dokumen elektronik, majalah artikel, e-article, buku, e-book, cetakan iklan, iklan TV, iklan jaringan, telepon, telepon sel, telepon internet, surat suara, telemarketing, fax, pager, web, e-mail, selebaran, simulasi, basis data, multimedia presentasi, slides, disket, tape, vidio, CD ,DVD, radio, radio TV, TV jaringan, teleconferens. Dan yang menjadi kaharusan manusia dalam kehidupan ini adalah harus mampu menguasai komputer dasar sampai kepada suatu tingkat yang lebih tinggi untuk kelancaran `digital` dan mampu menggunakan berbagai perangkat (software) berbasis komputer untuk melaksanakan tugas hidup seharihari. Dalam hidup ini kita dihadapkan banyak sekali pilihan pekerjaan dan tentunya permasalahan hidup menuntut kita berketrampilan efektif dan berfikir tingkat tinggi, terkait dengan hal ini menjadi hal yang mustahil hanya mengandalkan pembelajaran di sekolah, manusia yang hidup di zaman ini dituntut menjadi pebelajar mandiri. 
Tabel Keterampilan yang Dipelajari dan Dicari dari Teknologi

\begin{tabular}{|l|l|}
\hline $\begin{array}{l}\text { Aktivitas yang difasilitasi } \\
\text { olehTeknologi }\end{array}$ & Hasil yang Diharapkan \\
\hline Manajemen pengetahuan & $\begin{array}{l}\text { Belajar mengungkap pengetahuan dan pengalaman untuk } \\
\text { pengembangan personaldan profesional; menanamkan } \\
\text { mentalitas pembelajaran berlanjut }\end{array}$ \\
\hline Produksi visual & $\begin{array}{l}\text { Belajar meneijemahkan informasi yang statis, kompleks } \\
\text { menjadi dinamis dan mudah dipahami }\end{array}$ \\
\hline Presentasi hasil kerja & Belajar membangun keterampilan komunikasi efektif \\
\hline Ringkasan eksekutif & $\begin{array}{l}\text { Belajar membangun keterampilan menulis efektif, mengubah } \\
\text { sejumlah besar informasi menjadi ringkasan pengetahuan yang } \\
\text { kritis }\end{array}$ \\
\hline Projek kelompok & $\begin{array}{l}\text { Mengarahkan pengembangan interpersonal dan keterampilan } \\
\text { manajemen projek }\end{array}$ \\
\hline Kolaborasi virtual praktis & $\begin{array}{l}\text { Nilai pembelajaran di rumah sepanjang hari mengenai } \\
\text { pekerjaan dan kolaborasi jarak jauh dengan teman pada masa- } \\
\text { masa akhir pertemuan }\end{array}$ \\
\hline
\end{tabular}

2) Peran Pendidikan di Era Digital (Abad 21)

a) Memperkuat Sains dan Mengembangkan Kreativitas

Dalam memperkuat Sains Diperlukan adanya pendidik profesional yakni guru di sekolah dasar dan menengah, serta dosen di perguruan tinggi (Kusuma \& Caesarani, 2019). Pelajaran Matematika perlu diberikan kepada semua peserta didik mulai dari sekolah dasar sampai sekolah tinggi, untuk membekali peserta didik dengan kemampuan berpikir logis, analitis, sistematis, kritis, dan kreatif, serta kemampuan bekerja sama. Kemampuankemampuan tersebut sangat dibutuhkan oleh semua peserta didik agar mereka mampu bertahan pada keadaan yang selalu berubah, tidak pasti, dan kompetitif (Utami \& Khoiroh, 2019)

Berkaitan dengan hal ini Tilaar (2002), menyarankan guna memperkuat pendidikan dan kebutuhan akan sains terhadap siswa perlu diperkuat dengan penguasaan mata pelajaran matematika, karena muatan mata pelajaran matematika merupakan gambaran dari cara berfikir sains, selain itu perlu juga sekolah dilengkapi laboratorium sains yang memadai untuk menunjang pelajaran tersebut. Hal yang lain adalah pendidikan karakter berkpribadian dan kreativitas. Adanya Informasi yang tak terbatas memungkinkan seseorang untuk menciptakan hal baru, namun terkadang juga menyebabkan seseorang tenggelam dalam timbunan informasi yang membingungkan sehingga seseorang tidak dapat mengambil keputusan dan hasilnya menjadi absurd. Oleh sebab itu, salah satu sikap yang perlu dikembangkan dalam era ini adalah mengembangkan sikap kreativitas dan kompetensi secara seimbang.

b) Mengembangkan Pendidikan Digital, Hubungan Partisipatif, dan Pendidikan Nilai

Memasuki era revolusi industri 4.0 atau revolusi industri dunia keempat dimana teknologi informasi dan komunikasi telah menjadi basis dalam kehidupan manusia, maka harus direspon secara cepat dan tepat oleh pemangku kepentingan (Defrizal et al., 2019). Dalam dunia pendidikan sekarang ini dimana tuntutan kualitas dan mutu menjadi tuntutan, maka perlu dikembangkan pendidikan yang berbasis digital di mana setiap satuan pendidikan terkoneksi dalam jaringan internet dengan penguasan teknologi digital yang baik untuk saling tukar informasi, dan lain-lain. Terkait dengan pendidikan tinggi, perguruan tinggi perlu meletakan hubungan partisipatif dengan dunia usaha dan lembaga-lembaga penelitian. Posisi nya cenderung hanya terkesan bersifat formal dan seremonial dan bahkan keduanya terkesan 
menjaga jarak dengan keangkuhannya masing-masing. Dan yang tidak kalah penting adalah bahwa memahami hakikat pendidikan nilai sebagai pelestari budaya bangsa.

c) Mereorientasi Pembelajaran

Hasil perjalanan hidup manusia sangatlah ditentukan oleh sejauh mana ketaatan manusia melakukan segala perintahnya dan menjauhi larangannya dengan tetap istiqomah di jalan Allah SWT. Istiqamah dalam hal apapun, termasuk di dalamnya terkait dengan pendidikan. Pendidikan yang di maksud adalah keharusan manusia untuk mencari ilmu dan pengetahuan (Fatoni \& Fatoni, 2017). Perubahan hidup menusia mendorong lahirnya pengenbangan teknologi dan informasi yang memungkinkan manusia dapat bisa manfaatkan dalam kehidupannya. Tuntutan atas hal ini mempengaruhi orentasi dalam pembelajran. Perubahan reorientasi dalam pembelajaran itu menyangkut beberapa hal yaitu dari; 1) menggeser paradigma pembelajaran dari asumsi tersembunyi bahwa pengetahuan dapat dipindahkan secara utuh dari otak/pikiran guru ke otak/pikiran siswa untuk menuju pembelajaran yang lebih `memberdayakan`seluruh aspek kemampuan siswa. 2) mengeser paradigma pembelajaran dari berpusat pada guru (teacher centred learning) menuju pembelajaran yang berpusat pada siswa (student centred learning), self directed learning (belajar mandiri), dan pemahaman diri (metakognisi) karena pembelajaran ini dirasa lebih memberdayakan siswa dalam segala aspek. 3) menggeser dari belajar "menghafal" konsep menuju belajar menemukan dan membangun (mengkonstruksi) sendiri konsep, yang terbukti mampu meningkatkan kemampuan siswa dalam berfikir tingkat tinggi, kritis, kreativ dan terampil memecahkan masalah, 4) menggeser dari belajar individual klasikal menuju pembelajaran kelompok kooperatif yang tidak hanya mengajari keterampilan berfikir saja namun juga mampu mengajari siswa keterampilan-keterampilan lainnya (keterampilan sosial).

Pembelajaran lainnya yang menekankan $3 \mathrm{~T}$ (teknology, Teaming, Tranference), dengan kata lain pembelajaran diwanai dan diarahkan terbentuknya penguasaan komputer, penggalang kerjasama dan penguasaan bahasa Inggris. Pembelajaran yang menekankan: membaca, menulis dan menghitung, tetap diperhatikan untuk memberi jembatan kearah penguasan komputer, bahasa dan kerjasama. Tugas yang diberikan anak adalah tugas besar (big task) yang menantang untuk melakukan kerja lapangan dan pemanfaatan teknologi komputer. Prinsip belajar (problem-solving) ditekankan, menghindari belajar hafalan (rote learning). Belajar secara kontekstual ditekankan untuk mendorong prinsip belajar yang bermakna. Asesment yang berorientasi pada authentic assessment ditekankan. Dengan kata lain, Indonesia perlu meniru Amerika untuk berpikir tentang masa depan seawal mungkin dalam mempersiapkan sumber daya masa depan dan menata kembali sistem dan praktik pendidikan. Sebuah langkah yang harus didukung oleh semua pihak.

Menurut Sidi (2001) paradigma learning jelas terlihat dalam empat visi pendidikan menuju abad 21 versi UNESCO, yakni: 1) learning to think (belajar berpikir). Ini berarti pendidikan berorientasi pada pengetahuan logis dan rasional sehingga leaner berani menyatakan pendapat dan bersikap kritis serta memiliki semangat membaca yang tinggi; 2) learning to do (belajar berbuat/hidup) hal ini terkait keterampilan siswa menyelesaikan problem keseharian atau pendidikan diarahkan pada how to solve the problem; 3) learning to live together (belajar hidup bersama) hal ini terkait pembentukan siswa yang berkesadaran bahwa hidup ini dalam sebuah dunia yang global bersama banyak manusia dari berbagai bahasa dengan latar belakang etnik, agama dan budaya. Jadi hal ini terkait akan nilai-nilai perdamaian, penghormatan HAM, pelestarian hngkungan hidup, toleransi, menjadi aspek utama yang mesti mengintemal dalam kesadaran leaner; 4) learning to be (belajar menjadi diri sendiri) hal ini penting karena masyarakat modem dilanda krisis kepribadian. Karena itu bagaimana seorang siswa di masa depannya bisa tumbuh dan berkembang sebagai pribadi yang mandiri, memiliki harga diri dan tidak sekedar memiliki materi dan jabatan politis. 
Menurut Susilo (2011) ada enam unsur pembelajaran abad 21 yaitu: 1) menekankan pada mata pelajaran utama (Core subject knowledge), papun keterampilan yang dikembangkan, harus didasarkan pada pengetahuan mengenai isi materi mata pelajaran utama dan pemahaman mengenai ciri materi utama tersebut; 2) menekankan pada pengembangan keterampilan belajar; 3) memanfaatkan alat belajar abad 21 untuk mengembangkan keterampilan belajar; 4) membelajarkan siswa dalam konteks abad 21, siswa perlu belajar materi pelajaran melalui contoh-contoh, penerapan, dan pengalaman dunia nyata, baik di dalam,maupun luar sekolah;

d) Mengubah Peran Kosumen sekaligus Menjadi Produsen

Keadaan ekonomi masyarakat era digital mengimplikasikan agar pendidikan mampu mengubah jumlah penduduk yang begitu besar yang berperan sebagai konsumen agar sekaligus juga menjadi produsen. Bentuk implikasi secara khusus dari hal tersebut dapat berupa upaya perubahan mindset konsumtif.

e) Menghasilkan Lulusan Siap Kerja, Adaptif, dan Kompetitif

Dalam proses pembelajaran, guru tidak hanya dituntut menyampaikan materi pelajaran tetapi juga harus mampu mengaktualisasikan peran strateginya dalam upaya membentuk watak peserta didik melalui pengembangan kepribadian dan nilai-nilai yang berlaku. Agar tercipta tujuan pembelajaran, kesiapan yang matang diperlukan dari aspek guru sebagai penyampai pesan, maupun peserta didik sebagai perespon serta pekontruksi pengetahuan (Hadi, 2020).

Dunia kehidupan nyata saat ini tidak akan pernah berhenti untuk selalu membicarakan tentang pendidikan dalam berbagai sudut pandang dan permasalahan yang melingkupinya (Fatoni, 2017). Pendidikan harus mampu menghasilkan lulusan yang memiliki kemampuan memadai untuk masuk lapangan kerja dan atau menciptakan lapangan kerja baru; mampu beradaptasi dengan tuntutan perubahan dalam bidang profesinya dan pada akhirnya setiap lulusan program pendidikan harus mampu bersaing dengan tenaga kerja asing. Segala hal tersebut dilakukan agar pendidikan dapat memiliki keterkaitan dan kesepadanan (link and match) dengan kebutuhan masyarakat sehingga lulusan yang dihasilkan dapat langsung terserap oleh dunia kerja.

f) Memberdayakan Peserta Didik dalam Aplikasi Sains dan Teknologi

Dengan berkembangnya teknologi dan kehidupan generasi peserta didik yang saat ini sangat dekat dengan teknologi, maka sudah seharusnya dibrikan ruang untuk pemanfaatan kelas belajar dengan model e-learning melalui metode blended learning. Seiring dengan berjalannya waktu, kebutuhan manusia semakin berkembang dan bertambah. Penemuan teknologi-teknologi baru menjadi salah satu faktor penunjang bertambahnya kebutuhan baru dalam segala bidang, termasuk pada bidang pendidikan (Herlandy \& Novalia, 2019).

Namun demikian, paradigma terhadap pembelajaran matematika (sains) sampai saat ini masih tergolong sangat memprihatinkan. Tidak sedikit orang yang menganggap pelajaran matematika sebagai pelajaran yang sulit, membosankan, dan terlebih lagi menganggap pelajaran matematika sebagai pelajaran yang menakutkan. Seperti yang kita ketahui, akan sangat sulit memahami suatu materi yang sedang dijelaskan, jika orang tersebut tidak mau terlibat dalam proses pembelajaran karena alasan sulit, bosan, dan takut (Hamidah; Jaka Wijaya Kusuma, 2020).

Selanjutnya, berbagai kecenderungan dan tantangan berkaitan dengan sains dan teknologi pada masyarakat era digital mengimplikasikan agar pendidikan mampu memberdayakan peserta didik sehingga mampu menyerap, mengembangkan dan mengaplikasikan sains dan teknologi dalam berbagai bidang kehidupan secara bijaksana. Adapun teknologi yang perlu diserap, dikembangkan dan diaplikasikan itu adalah adalah teknologi tepat guna, baik berkenaan dengan teknologi yang ramah lingkungan dan bersahabat 
dengan masyarakat. Terlebih lagi pendidikan tinggi, Selain itu, perguruan tinggi hendaknya mampu meningkatkan daya sahutnya dalam rangka pengembangan sains dan teknologi.

g) Mengoptimalkan Pelayanan Pendidikan Non Formal

Dalam mencapai kesuksesan dibidang kewirausahaan pun mutlak harus dimiliki pengetahuan tetang kewirausahaan (Fajar Diah Astuti, Rawit Sartika, 2020). Peran pendidikan dalam menyiapkan pelaku bisnis tradisional memasuki era digital yakni dengan mengoptimalkan pelayanan Pendidikan Non Formal (PNF) bagi pemberdayaan masyarakat, khususnya para pelaku bisnis tradisonal dengan program-program yang berorientasikan bisnis era digital.

Menurut Kindervatter (1979) peran PNF dalam proses pemberdayaan secara minimal pertama, kebudayaan edukatif yang meliputi kategori kualitas: melek huruf, melek pendidikan dasar, memiliki keterampilan, pengetahuan, kreatif, inovatif, dan sebagainya. Kedua, keberdayaan ekonomi, yaitu mampu memahami dan mengendalikan factor-faktor ekonomi yang mempengaruhi kehidupannya, sehingga dapat berpartisipasi secara produktf dan efisien dalam pembangunan, serta memperoleh hasil dari pembangunan Ketiga, keberdayaan politik, mampu memahami fenomena dan kebijakan politik yang mempengaruhi kehidupan pribadi dan sosialnya, sehingga dapat melaksanakan kewajiban dan mendapatkan haknya sebagai warga Negara secara maksimal. Keempat, keberdayaan hukum, memahami dan mengendalikan regulasi social, aturan yang mempengaruhi kehidupannya, sehingga mendapatkan perlakuan dan perlindungan hukum secara adil.

h) Mengoptimalkan Konstribusi Pendidikan terhadap Pembangunan Ekonomi

Pendidikan adalah hal pokok untuk menggapai kehidupan yang memuaskan dan bermartabat. Pendidikan termasuk hal yang fundamental untuk membentuk kapabilitas manusia yang lebih luas yang berada pada makna inti pembangunan. Pendidikan memainkan peran kunci dalam membentuk kemampuan sebuah Negara berkembang untuk menyerap tekhnologi modern dan untuk mengembangkan kapasitas agar tercipta pertumbuhan dan pembangunan yang berkelanjutan. Pendidikan memberi kontribusi secara sigfikan terhadap pembangunan ekonomi telah menjadi kebenaran yang bersifat aksiomatik. Berbagai kajian akademis dan penelitian empiris telah membuktikan keabsahannya. Pendidikan bukan hanya menetaskan sumber daya manusia yang berkualitas, memiliki pengetahuan dan keterampilan serta menguasai teknologi, tetapi juga dapat menumbuhkan iklim bisnis yang sehat dan kondusif bagi pertumbuhan ekonomi. Karena itu, investasi di bidang pendidikan tidak saja bermanfaat bagi individu saja, tetapi juga bagi komunitas bisnis dan masyarakat umum.

Pencapaian pendidikan pada semua level dan kalangan niscaya akan meningkatkan pendapatan dan produktivitas masyarakat. Pendidikan merupakan jalan menuju kemajuan dan pencapaian kesejahteraan sosial serta ekonomi. Sedangkan kegagalan dalam membangun pendidikan akan dapat melahirkan berbagai masalah dan problem yang krusial: seperti adanya pengangguran, kriminalitas, penyalahgunaan narkoba, dan welfare dependency yang menjadi beban sosial politik bagi pemerintah.

Setidaknya ada tiga paradigma yang menegaskan bahwa pembangunan memiliki dimensi nyata dalam dunia pendidikan merujuk pada konsep knowledge based economy tampak semakin dominan yaitu : 1). Kemajuan ekonomi dalam banyak hal bertumpu pada basis dukungan ilmu pengetahuan dan teknologi. 2). Hubungan kausalitas antara pendidikan dan kemajuan ekonomi menjadi kian kuat dan solid. 3). Pendidikan menjadi penggerak utama dinamika perkembangan ekonomi, yang mendorong proses transformasi struktural berjangka panjang. 


\section{SIMPULAN}

Bisnis tradisional adalah bisnis yang dikelola menggunakan sistem ekonomi tradisional di mana setiap aktivitas perekonomian dilakukan bertujuan untuk memenuhi kebutuhan hidup dengan melakukan kebiasaan atau tradisi turun temurun. Bisnis tradisional dilakukan untuk memenuhi kebutuhan hidup, minim manajemen, dan berdasarkan kekeluargaaan. Sedangkan bisnis modern (mencakup bisnis online) adalah bisnis yang menggunakan sistem ekonomi kapital, yang memiliki ciri-ciri spesialisasi, saling ketergantungan, dan berproduksi secara massal. Bisnis ini tujuan utamanya adalah profit atau keuntungan. Bisnis modren cenderung memiliki kapasitas dan skala usaha yang lebih luas, dengan jangkauan setiap kota atau bahkan setiap negara. Perebedaan di antara kedua bisnis tersebut meliputi aspek-aspek: pola merintis dan mengembangkan bisnis, pelayanan terhadap konsumen, mitra bisnis, harga, Jenis barang atau jasa, pemasaran, skala usaha, manajemen bisnis

Peluang dan tantangan bisnis di era digital antara lain meliputi perkembangan Teknologi yang kian pesat, derasnya arus informasi, kompetitor semakin banyak, tuntutan serba cepat, masyarakat yang berubah, tuntutan terus menerus belajar, inovatif dalam menciptakan produk, berpikir out of the box, mampu bersaing secara sehat, transformasi digital, kecepatan, sumber daya manusia yang adaptif, persaingan semakin tinggi, dan kurangnya dukungan pemimpin. Peran pendidikan di era digital antara lain meliputi (1) memperkuat sain dan mengembangkan kreativitas, (2) mengembangkan pendidikan digital, hubungan partisipatif, dan pendidikan nilai, (3) mereorientasi pembelajaran, (4) mengubah peran kosumen sekaligus menjadi produsen, (5) menghasilkan lulusan siap kerja, adaptif, dan kompetitif, (6) memberdayakan peserta didik dalam aplikasi sains dan teknologi, (7) mengoptimalkan pelayanan pendidikan non formal bagi pemberdayaan masyarakat, dan (8) mengoptimalkan konstribusi pendidikan terhadap pembangunan ekonomi.

\section{DAFTAR RUJUKAN}

Alami, T. (2019). Faktor-Faktor yang Mempengaruhi Keselarasan Strategi Teknologi Informasi dan Bisnis pada Pendidikan Tinggi. Journal of Education Informatic Technology and Science, 1(2), 13-26. https://doi.org/10.37859/jeits.v1i2.1369

Badan Standar Nasional Pendidikan. (2010). Paradigma Pendidikan Nasional Abad XXI. Jakarta: BSNP.

Baskoro, A.P. (2009). Mempersiapkan Generasi di Abad 21. (online), (http://baskoro.blogspot.com/2009/06/mempersiapkan-generasi-diabad-21-

html/, diakses 20 Januari 2010).

Cintamulya, Imas. Peranan Pendidikan dalam Mempersiapkan Sumber Daya Manusia Di Era Informasi Dan Pengetahuan. Jurnal Formatif 2(2) 90-101. Jawa Timut: Universitas PGRI Ronggolawe Tuban.

Defrizal, H., Vilmala, B. K., \& Al Rian, R. (2019). Pada Pembelajaran Program Studi Pendidikan Ipa. JeiITS, 1(Vol 1 No 1 (2019): Journal of Education Informatic Technology and Science (JeITS)), 34-43. http://ejurnal.umri.ac.id/index.php/JeITS/article/view/1229

Fajar Diah Astuti, Rawit Sartika, P. S. (2020). PENGARUH TINGKAT PENGETAHUAN KEWIRAUSAHAAN TERHADAP MINAT MENJADI ENTREPRENEUR PADA MAHASISWA (Studi kasus mahasiswa UBSI cabang Salemba 22 Jakarta). Jurnal Pendidikan Dan Kewirausahaan, 7(2), 1-12. https://doi.org/10.1017/CBO9781107415324.004

Fatoni, M. (2017). Peran Kepala Madrasah Dalam Meningkatkan Mutu Guru Di Mts Nurul Falah Talok Kresek Kabupaten Tangerang. Tarbawi: Jurnal Keilmuan Manajemen 
Pendidikan, 3(02), 168. https://doi.org/10.32678/tarbawi.v3i02.1787

Fatoni, M., \& Fatoni, M. (2017). TEOLOGI PENDIDIKAN: STUDI ANALISA PENGUATAN DALAM KARAKTERISTIK PENDIDIKAN ISLAM. Geneologi PAI: Jurnal Pendidikan Agama Islam, 3(1), 51-68. http://www.jurnal.uinbanten.ac.id/index.php/geneologi/article/view/228

Galbreath J. (1999). Preparing The 21st Century Worker: The Link Between Computer Based Technology And Future Skill Sets. Educational Technology.

Hadi, H. purwanto. (2020). Peranan Ingatan Serta Implikasinya Dalam Proses Pembelajaran. Journal of Education Informatic Technology and Science, 2(3), 45-54. https://doi.org/10.37859/jeits.v2i3.1687

Hamidah; Jaka Wijaya Kusuma. (2020). KOLABORASI PEMBELAJARAN ASSURANCE -RELEVANCE-INTEREST-ASSESSMENT-SATISFACTION DENGAN THINKTALK-WRITE UNTUK MENINGKATKAN KEMAMPUAN PENALARAN KREATIF MATEMATIK DAN MOTIVASI BERPRESTASI SISWA. Jurnal Lebesgue : Jurnal Ilmiah Pendidikan Matematika, Matematika Dan Statistika, 1(1), 5662. https://doi.org/10.46306/lb.v1i1

Herlandy, P. B., \& Novalia, M. (2019). Penerapan e-Learning pada Pembelajaran Komunikasi dalam Jaringan dengan Metode Blended learning Bagi Siswa SMK. Journal of Education Informatic Technology and Science, 1(1), 24-33.

Kusuma, J. W., \& Caesarani, S. (2019). Penerapan Pendekatan Konflik Kognitif Terhadap Pemahaman Konsep Matematis Siswa Di Smp Negeri 7 Kota Serang. JIPMat, 4(1), 2027. https://doi.org/10.26877/jipmat.v4i1.3500

Mangunwijaya, Y. B. (1987). Teknologi dan Dampak Kebudayaan, Volume I. (Cetakan Kedua). Jakarta: Yayasan Obor.

Noer, D. dan Alisyahbana, I. (1988). Perubahan, Pembaharuan dan Kesadaran Menghadapi Abad Ke-21. Jakarta: PT. Dian Rakyat. Pidarta, M. (2007). Wawasan Pendidikan. Surabaya: Unesa Press.

Putra, R. M. (2019). PENGARUH PEMANFAATAN INTERNET DAN MOTIVASI BELAJAR TERHADAP HASIL BELAJAR SISWA KELAS VII DI SMP NEGERI 1 KAPONGAN TAHUN PELAJARAN 2015/2016 Rizka Mahendra Putra. 6(1), 13-22.

Syah, M. (2015). Psikologi Belajar. Jakarta: Raja Grafindo.

Setiawan, Wawan (2017). Era Digital dan Tantangannya. Seminar Nasional Pendidikan. UPI.

Sidi, I.D. (2001). Menuju Masyarakat Belajar: Menggagas Paradigma Baru Pendidikan. Jakarta: Paramadina.

Sujarweni, V.Wiratna, (2014). Metodeologi Penelitian. Yogyakarta : Pustaka Baru Perss.

Susilo, H. 2011. Bended Learning untuk Menyiapkan Siswa Hidup Di Abad 21. Universitas Negeri Malang. Seminar Nasional Pengembangan Pembelajaran Berbasis Blended Learning.

Syaripudin, T. (2007). Landasan Pendidikan. Bandung: Percikan Ilmu.

Tilaar, H.A.R. (2002). Membenahi Pendidikan Nasional. Jakarta: Rineka Cipta.

Utami, D. R., \& Khoiroh, F. (2019). Pengaruh Model Pembelajaran Pbl Berbantuan Edmodo Terhadap Kemampuan Representasi Matematika Siswa. 1, 21-25.

Wiratna Sujarweni, V., \& Laut Mertha Jaya, I. M. (2019). Pengelolaan Keuangan Bumdes Sambimulyo di Kawasan Geoheritage "Tebing Breksi” Yogyakarta. Jurnal Ilmiah Padma Sri Kreshna, 1(2), 13-17. https://doi.org/10.37631/psk.v1i2.73 